Original Research

\title{
The Risk of Mortality on Patients with Traffic Accidents of Emergency Department at dr. Soebandi Regional Hospital, Jember Regency
}

\section{Baskoro Setioputro, Indah Listiyawati, Kholid Rosyidi Muhammad Nur}

Jember University, East Java, Indonesia

\begin{abstract}
Introduction: The number of deaths due to traffic accidents has become a global burden. In addition SDGs 2030 has set a target to decrease the number of fatalities and global injuries due to traffic accidents. The purpose of this study was to analyse the risk of mortality due to traffic accidents in the Emergency Department (ED) of dr.Soebandi Hospital Regional, Jember Regency.
\end{abstract}

Methods: A retrospective observational study was carried out in the ED by studying medical records of the traffic accident patients aged $\geq 16$ years. The sampling technique was simple random sampling with sample size 250 . The study collected data with Modified Rapid Emergency Medicine Score. This study result was analyzed with frequency distribution and Chi-square test.

Results: The result showed respondents who experienced traffic accidents were mostly 20-29 years old (19.6\%). The majority of the patients were men (68.4\%). The riders of two/three-wheeled vehicles who suffered traffic accidents reached $73.2 \%$. Most of the accidents occurred between 06.00-11.59am, 37.6\%. Generally, traffic accidents occur to drivers as much as $68.4 \%$ and the number of types of head trauma as much as $57.2 \%$. This study showed that $94.8 \%$ patients were at low risk of mortality. There was significant relationship between risk of mortality and the role in vehicle use ( $p$-value $=0.043$ ).

Conclusion: Almost all patients have a low risk of mortality in the ED of dr. Soebandi Hospital Jember Regency.

\section{ARTICLE HISTORY}

Received: January 27, 2020

Accepted: April 26, 2020

\section{KEYWORDS}

risk of mortality; emergency department (ED); traffic accident.

\section{CONTACT}

Baskoro Setioputro $\triangle$ bsetioputro@gmail.com $\doteqdot$ Jember University East Java, Indonesia

Cite this as: Setioputro, B., Listiyawati, I., \& Nur, K. R. M. (2020). The Risk of Mortality on Patients with Traffic Accidents of Emergency Department at dr. Soebandi Regional Hospital, Jember Regency. Jurnal Ners, 15(1), X-X. doi:http://dx.doi.org/10.20473/jn.v15i1.17599

\section{INTRODUCTION}

Traffic accidents can increase mortality rates for vulnerable road users, such as bicycle riders, motor riders and pedestrians. Mortality rate due to traffic accidents is still a global burden and the 3.6th target of the Sustainable Development Goals 2030 program (SDGs) is to reduce half of global mortality and injury rates by 2020 (WHO, 2018; ILO, 2018). During the period 01 January to 30 December 2018, the number of traffic accidents in Indonesia reached 108,873 accidents with a total mortality of 25,511 people (National Traffic Police, 2019). One of the provinces contributing mortality rates due to traffic accidents is East Java. The number of traffic accidents in East Java during the period 01 April to 30 June 2019 reached 423 accidents with a total mortality of 104 victims (National Traffic Police, 2019). On the other hand, Jember Police data revealed that traffic accidents in
2018 reached 1,260 accidents with a total mortality of 379 victims (Wahyunik, 2019).

Traffic accidents can cause emergency condition for the victim (Ministry of Health of the Republic of Indonesia, 2016). Therefore it requires treatment within the first hour or what is often called as the golden period to save the victim (Korlantas Polri, 2019). One of the initial steps to save victims is determining risk of mortality in prioritizing victim care in health facilities. The Rapid Emergency Medicine Score (REMS) observation sheet can be used to determine patient's risk of mortality (Seak et al., 2017). Based on research by Nakhjavan-Shahraki, Bikpour, Youseifard, Nikhseresht, Razaz, Faridaalaee, and Hossein (2017), REMS can predict mortality events and adverse effects on patients in the Emergency Department. 
However, REMS has a lower validity value than the Modified Rapid Emergency Medicine Score (mREMS) in determining the incidence of mortality in trauma patients. REMS validity value is $91.1 \%$ and $92.1 \%$ for mREMS. In addition, mREMS is suitable to apply in trauma cases. mREMS is better than some other trauma scores, such as the Mechanism of Glasgow Coma Scale and Arterial Pressure (MGAP), Revised Trauma Score (RTS), Injury Severity Score (ISS), Shock Index (ISS), and Shock Index SI). mREMS score range is between 0 and 26. Patients who have mREMS score 0 to 2 reached 70 mortalities $(0.03 \%)$ out of 221,684 victims, while trauma patients having mREMS score 22 to 26 reached 1,781 mortality $(91.2 \%)$ out of 1,952 victims. The higher the value of mREMS, the higher the mortality rate of patients with trauma (Miller et al., 2017).

The mREMS instrument consists of age, Systolic Blood Pressure (SBP), heart rate (HR), respiratory rate (RR), oxygen saturation, and Glasgow Coma Scale (GCS). These variables are needed by the EMS (Emergency Medical Service) officer or triage officer to check the patient's health status in making the decision to transport the victim to the most appropriate facility (Miller et al., 2017). Thus, it is important to know the score of the mREMS at the Hospital ED, which is the first emergency service.

Emergency services are expected to prevent the risk of disability and mortality in patients (to save life and limb) (Korlantas Polri, 2019). Emergency Departments experience an increase in the number of patient visits each year (Deviantony et al., 2017). Based on data from the dr. Soebandi Regional Hospital Emergency Department there were 2,402 patients with traffic accident in 2018. Therefore, it is important to know the patient's condition in preventing mortality, especially in the hospital emergency department. The assessment of mortality scores with mREMS is unknown in the dr. Soebandi Regional Hospital Emergency Department. This study aimed to analysis the risk of mortality patients with traffic accidents in the dr. Soebandi Regional Hospital Emergency Department, Jember Regency

\section{MATERIALS AND METHODS}

Quantitative research with retrospective approach was used in this study. Retrospective observational research is a research conducted on events that have occurred to see the risk factors of the causes of these events (Nursalam, 2015). This research was conducted for one month (December 2019-January 2020) using a variable risk level of patient mortality due to traffic accidents and the risk factors for mortality in the dr. Soebandi Regional Hospital, Emergency Department, Jember Regency. The population in this study is the data of medical records of patients with traffic accidents in the dr. Soebandi Regional Hospital, Emergency Department, Jember Regency in January to December 2018; there were 2,402 population while the number of samples used in the study was 250 .
This study used probability sampling, which is a sampling technique by giving equal opportunities to each population to be selected as a sample (Sastroasmoro \& Ismael, 2014). The technique in sampling used simple random sampling by randomization. This technique is a random sampling technique without considering strata in the population (Sugiyono, 2015). The instrument used in this study was the mREMS observation sheet. The mREMS component consists of age, SBP, HR, RR, SpO2 and GCS that are measured when the patient is in the first triage or during the primary survey. The AUC value of mREMS has been tested for validity and reliability by Miller, Nazir, McDonald and Cannon (2017) of 0.967 (95\% CI (Confidence Interval): 0.9630.971 ) which means that the validity level of mREMS is $96.7 \%$ to predict mortality of trauma patients in the hospital. mREMS had three categories in the risk of mortality: low risk (score 0-8), moderate risk (score 9-17), and high risk (18-26) (Miller et al., 2017).

This study employed univariate analysis of patient characteristics (such as age, education, gender, and occupation), season, day of traffic accident, time of traffic accident, type of road, role of patient using vehicle, type of trauma, patient information and level risk of mortality. The component is analyzed by percentage and frequency distribution. This study also employed bivariate analysis with Chi-square test. The Chi-square test was used for relationship between categorical variables with the risk of mortality $(p<0.05)$. The research ethics were approved on October 21, 2019, by the ethics committee of the Faculty of Dentistry, University of Jember based on a certificate of ethical qualification number 594 / UN25.8 / KEPK / DL / 2019.

\section{RESULTS}

Respondent characteristic, risk factors, and risk of mortality of traffic accident patients were analyzed in this present study. Table 1 shows that the highest data of traffic accident patients characteristic in the dr. Soebandi Regional Hospital, Emergency Department, Jember Regency, in 2018 was age group of 20-29 years with 49 patients (19.6\%), and 171 male patients $(68.4 \%)$ with 94 high school education level patients $(37.6 \%)$. Based on the type of employment often involved in crashes are farmers with 57 patients $(22.8 \%)$. Table 1 shows that the characteristics of respondents' age, gender, education, and job had no significant relationship with risk of mortality.

Table 2 shows that, according to type of user, 2/3wheeled motorized vehicles with about 183 patients $(73.2 \%)$ became the highest case. Based on the distribution of the day, the highest accident occurrence was on Wednesday as many as 46 patients $(18.4 \%)$ and Sunday as many as 40 respondents (16\%), while based on the time of the incident there were 94 patients (37.6\%) who had an accident at 06.00-11.59am. There were 134 respondents (54.0\%) who had accidents in the dry season 
dominated by drivers as many as 171 respondents (68.4\%). The most types of trauma were head trauma of 143 respondents (57.2\%) out of 250 respondents and referral patients were 158 respondents (63.2\%). Table 2 found significant relationship in the role in vehicle use between risk of mortality $(p=0.043$ $<0.05$ ), but there wasn't a significant relationship in type of road, the day of occurrence, time of occurrence, season, type of trauma and patient information between the risk of mortality.

Table 3 illustrates the level of risk of mortality of patients due to traffic accidents in the dr. Soebandi Regional Hospital Emergency Department in Jember Regency that in 2018 there were 237 patients (94.8\%) who had a low risk of mortality. The high risk of mortality is 12 patients (4.8\%) and the lowest level risk of mortality is a high risk of one patient $(0.4 \%)$

\section{DISCUSSION}

This study analyzed 250 medical records from patients with traffic accident in the dr. Soebandi Regional Hospital, Emergency Department, Jember Regency. Most of the study samples or 237 patients $(94.8 \%)$ had a low risk of mortality. Trauma patients death reached $6.0 \%$ with the highest proportion of head /spinal trauma patients (67\%) (Eaton et al., 2017). In addition, other studies also showed $4.5 \%$ deaths in motorbike traffic accident, treated in ward (82.5\%) and ICU (13\%) (Fouda et al., 2016).

The high risk of mortality was caused by traffic accident. Traffic accidents can cause casualties to become an emergency (Ministry of Health of the Republic of Indonesia, 2016). An emergency case is a situation that can threaten a victim's life. Emergency case requires immediate treatment to reduce the

Table 1. The Relationship Between the Characteristics of Patients with the Risk of Mortality in the ED of dr. Soebandi Hospital, Jember Regency, in 2018 ( $\mathrm{n}=250$ )

\begin{tabular}{|c|c|c|c|c|c|c|c|c|}
\hline \multirow{4}{*}{$\begin{array}{l}\text { Characteristics of } \\
\text { respondents }\end{array}$} & \multicolumn{8}{|c|}{ Risk of Mortality } \\
\hline & \multicolumn{6}{|c|}{ Frequency } & \multicolumn{2}{|c|}{ Totals } \\
\hline & \multicolumn{2}{|c|}{ Low Risk } & \multicolumn{2}{|c|}{ Moderate Risk } & \multicolumn{2}{|c|}{ High Risk } & \multirow[b]{2}{*}{$\mathbf{N}$} & \multirow[b]{2}{*}{$\%$} \\
\hline & $\mathbf{N}$ & $\%$ & $\mathbf{N}$ & $\%$ & $\mathbf{N}$ & $\%$ & & \\
\hline \multicolumn{9}{|l|}{ Age } \\
\hline $16-19$ & 43 & 95.6 & 2 & 4.4 & 0 & 0 & 45 & 100 \\
\hline $20-29$ & 48 & 98 & 1 & 2 & 0 & 0 & 49 & 100 \\
\hline $30-39$ & 31 & 100 & 0 & 0 & 0 & 0 & 31 & 100 \\
\hline $40-49$ & 45 & 93.8 & 3 & 6.2 & 0 & 0 & 48 & 100 \\
\hline $50-59$ & 35 & 94.6 & 2 & 5.4 & 0 & 0 & 37 & 100 \\
\hline $60-69$ & 27 & 87.1 & 3 & 9.1 & 1 & 0,1 & 31 & 100 \\
\hline$>69$ & 8 & 88.9 & 1 & 11.1 & 0 & 0 & 9 & 100 \\
\hline Totals & 237 & 94.8 & 12 & 4.8 & 1 & 0.4 & 250 & 100 \\
\hline Chi-square Test & \multicolumn{6}{|c|}{$p=0.427$} & & \\
\hline \multicolumn{9}{|l|}{ Gender } \\
\hline Man & 164 & 95.9 & 6 & 8.2 & 1 & 0,6 & 171 & 100 \\
\hline Woman & 73 & 92.4 & 6 & 7.6 & 0 & 0 & 79 & 100 \\
\hline Totals & 237 & 94.8 & 12 & 4.8 & 1 & 0.4 & 250 & 100 \\
\hline Chi-square Test & \multicolumn{6}{|c|}{$p=0.299$} & & \\
\hline \multicolumn{9}{|l|}{ Education } \\
\hline Not Schooling & 16 & 84.2 & 3 & 15.8 & 0 & 0 & 19 & 100 \\
\hline Primary School & 84 & 94.4 & 4 & 4.5 & 1 & 0,4 & 89 & 100 \\
\hline Middle School & 28 & 93.3 & 2 & 6.7 & 0 & 0 & 30 & 100 \\
\hline Senior High School & 92 & 97.9 & 2 & 2.1 & 0 & 0 & 94 & 100 \\
\hline College & 17 & 94.4 & 1 & 5.6 & 0 & 0 & 18 & 100 \\
\hline Totals & 237 & 94.8 & 12 & 4.8 & 1 & 0.4 & 250 & 100 \\
\hline Chi-square Test & \multirow{2}{*}{\multicolumn{6}{|c|}{$p=0.380$}} & & \\
\hline \multicolumn{6}{|l|}{ Job } & & & \\
\hline Not Working & 6 & 100 & 0 & 0 & 0 & 0 & 6 & 100 \\
\hline Government Employees & 11 & 100 & 0 & 0 & 0 & 0 & 11 & 100 \\
\hline General Employees & 40 & 90.9 & 3 & 6.8 & 1 & 2.3 & 44 & 100 \\
\hline Entrepreneur & 47 & 97.9 & 1 & 2.1 & 0 & 0 & 48 & 100 \\
\hline Housewife & 19 & 82.6 & 4 & 17.4 & 0 & 0 & 23 & 100 \\
\hline Farmer & 54 & 94.7 & 3 & 5.3 & 0 & 0 & 57 & 100 \\
\hline Student & 48 & 98 & 1 & 2 & 0 & 0 & 49 & 100 \\
\hline $\begin{array}{l}\text { Etc (Driver, Pedicab and } \\
\text { Wood Driver, Fisherman, } \\
\text { Trader) }\end{array}$ & 12 & 100 & 0 & 0 & 0 & 0 & 12 & 100 \\
\hline Totals & 237 & 94.8 & 12 & 4.8 & 1 & 0.4 & 250 & 100 \\
\hline Chi-square Test & \multicolumn{6}{|c|}{$p=0.301$} & & \\
\hline
\end{tabular}

* A statistically significant $(\mathrm{p}<0.05)$ 


\section{B. SETIOPUTRO ET AL.}

Table 2. The Relationship Between the Type of road, Day of Occurrence, Time of Occurrence, Season, Role in Vehicle Use, Type of Trauma and Patient Information with the Risk of Mortality in the ED of dr. Soebandi Hospital, Jember Regency, in $2018(n=250)$

\begin{tabular}{|c|c|c|c|c|c|c|c|c|}
\hline \multirow[t]{4}{*}{ Variable } & \multicolumn{8}{|c|}{ Risk of Mortality } \\
\hline & & & \multicolumn{2}{|c|}{ Frequency } & \multirow{2}{*}{\multicolumn{2}{|c|}{ High Risk }} & \multicolumn{2}{|l|}{ Totals } \\
\hline & \multicolumn{2}{|c|}{ Low Risk } & \multicolumn{2}{|c|}{ Moderate Risk } & & & \multirow[b]{2}{*}{$\mathbf{N}$} & \multirow[b]{2}{*}{$\%$} \\
\hline & $\mathbf{N}$ & $\%$ & $\mathbf{N}$ & $\%$ & $\mathbf{N}$ & $\%$ & & \\
\hline \multicolumn{9}{|l|}{ Type of Road } \\
\hline Pedestrian & 47 & 87 & 6 & 11.1 & 1 & 0,2 & & 100 \\
\hline Non-Motorized Vehicle Users & 8 & 100 & 0 & 0 & 0 & 0 & 8 & 100 \\
\hline $\begin{array}{l}\text { User of } 2 / 3 \text {-Wheeled Motorized } \\
\text { Vehicles }\end{array}$ & 177 & 96.7 & 6 & 3.3 & 0 & 0 & 183 & 100 \\
\hline $\begin{array}{l}\text { Motorized Vehicles } \geq 4 \text {-Wheeled } \\
\text { Motor }\end{array}$ & 5 & 100 & 0 & 0 & 0 & 0 & 5 & 100 \\
\hline Totals & 237 & 94.8 & 12 & 4.8 & 1 & 0.1 & 250 & 100 \\
\hline Chi-square Test & \multicolumn{8}{|c|}{$p=0.122$} \\
\hline \multicolumn{9}{|l|}{ Day of Occurrence } \\
\hline Monday & 29 & 87.9 & 4 & 12.1 & 0 & 0 & 33 & 100 \\
\hline Tuesday & 32 & 94.1 & 2 & 5.9 & 0 & 0 & 34 & 100 \\
\hline Wednesday & 44 & 95.7 & 2 & 4.3 & 0 & 0 & 46 & 100 \\
\hline Thursday & 33 & 100 & 0 & 0 & 0 & 0 & 33 & 100 \\
\hline Friday & 25 & 92.6 & 2 & 7.4 & 0 & 0 & 27 & 100 \\
\hline Saturday & 35 & 94.6 & 2 & 5.4 & 0 & 0 & 37 & 100 \\
\hline Sunday & 39 & 97.5 & 0 & 0 & 1 & 0,4 & 40 & 100 \\
\hline Totals & 237 & 94.8 & 12 & 4.8 & 1 & 0.1 & 250 & 100 \\
\hline Chi-square Test & \multicolumn{8}{|c|}{$\begin{array}{c}12 \quad{ }^{4}=0.850 \\
p=0.350\end{array}$} \\
\hline \multicolumn{9}{|l|}{ Time of Occurrence } \\
\hline 06.00-11.59 AM (Morning) & 89 & 94.7 & 5 & 5.3 & 0 & 0 & 94 & 100 \\
\hline $12.00-17.59$ AM (Noon) & 69 & 95.8 & 3 & 4.2 & 0 & 0 & 72 & 100 \\
\hline $18.00-23.59 \mathrm{AM}$ (Night) & 61 & 95.3 & 3 & 4.7 & 0 & 0 & 64 & 100 \\
\hline 00.00-05.59 AM (Early day) & 18 & 90 & 1 & 5 & 1 & 5 & 20 & 100 \\
\hline Totals & \multirow{2}{*}{\multicolumn{8}{|c|}{$\begin{aligned} 12 & =0.070^{4}\end{aligned}$}} \\
\hline Chi-square Test & & & & & & & & \\
\hline \multicolumn{9}{|l|}{ Season } \\
\hline Dry & 129 & 95.6 & 5 & 3.7 & 1 & 0.7 & 135 & 100 \\
\hline Rain & 108 & 93.9 & 7 & 6.1 & 0 & 0.4 & 115 & 100 \\
\hline Totals & 237 & 94.8 & 12 & 4.8 & 1 & 0.1 & 250 & 100 \\
\hline Chi-square Test & \multicolumn{8}{|c|}{$p=0.448$} \\
\hline Role in Vehicle Use & & & & & & & & \\
\hline Pedestrian & 47 & 87 & 6 & 11.1 & 1 & 1.9 & 54 & 100 \\
\hline Driver & 166 & 97 & 5 & 2,9 & 0 & 0 & 171 & 100 \\
\hline Passenger & 24 & 96 & 1 & 4 & 0 & 0 & 25 & 100 \\
\hline Totals & 237 & 94.8 & 12 & 4.8 & 1 & 0.1 & 250 & 100 \\
\hline Chi-square Test & & & & & & & & \\
\hline Type of Trauma & & & & & & & & \\
\hline Head Trauma & 130 & 90.9 & 12 & 8.4 & 1 & 0.7 & 143 & 57.2 \\
\hline Facial Trauma & 32 & 100 & 0 & 0 & 0 & 0 & 32 & 12.8 \\
\hline Neck and spinal Trauma & 4 & 100 & 0 & 0 & 0 & 0 & 4 & 1.6 \\
\hline Chest Trauma & 5 & 83.3 & 1 & 16.7 & 0 & 0 & 6 & 2.4 \\
\hline Abdomen and Pelvic Trauma & 5 & 100 & 0 & 0 & 0 & 0 & 5 & 2 \\
\hline Upper Extremity of Trauma & 52 & 98.1 & 1 & 1.9 & 0 & 0 & 53 & 21.2 \\
\hline Lower Extremity Trauma & 95 & 95 & 4 & 4 & 1 & 1 & 100 & 40 \\
\hline Totals & 323 & 129.2 & 18 & 7.2 & 2 & 0.8 & 343 & 137.2 \\
\hline Chi-square Test & & & & & & & & \\
\hline Patient Information & & & & & & & & \\
\hline Tranfer Patient & 147 & 93 & 10 & 6.3 & 1 & 0.6 & 158 & 100 \\
\hline Non-Transfer Patient & 90 & 97.8 & 2 & 2.2 & 0 & 0 & 92 & 100 \\
\hline Totals & 237 & 94.8 & 12 & 4.8 & 1 & 0.1 & 250 & 100 \\
\hline Chi-square Test & & & & & & & & \\
\hline
\end{tabular}

* A statistically significant $(\mathrm{p}<0.05)$

threat of life and an emergency situation needs to be handled quickly and appropriately to avoid the threat of life and disability in the limbs of the victim (Musliha, 2010). Thus, this requires treatment in the first hour, or what is often called the golden period, to save the victim's condition (Kartikawati, 2012). There are trimodal mortality patterns in trauma. The first periode is the risk of mortality caused by disorders of the heart, large blood vessels, brain and spinal cord system. The second periode is is the risk of mortality 
Table 3. Overview Risk of Mortality of Traffic Accident Patients $(n=250)$

\begin{tabular}{lcc}
\hline Mortality Risk & Frequency (n) & Percentage (\%) \\
\hline Low Risk & 237 & 94.8 \\
Moderate Risk & 12 & 4.8 \\
High Risk & 1 & 0.4 \\
Total & 250 & 100 \\
\hline
\end{tabular}

caused by intracranial bleeding, pelvic fracture and tears in solid organs bleeding. The third periode is the risk of mortality caused by sepsis, failure of some respiratory organs or other complications (American College Of Surgeons, 2018; Kartikawati, 2012; Sheehy, 2013).

This study showed one referral patient experienced the highest risk of mortality with an mREMS score 25. Patient had traffic accident between pedestrians and motorbikes on Sunday at 04.00am. The traffic accident was in early morning with vehicle tending to speeding because there are not many vehicles on the road. According to Rompis, Mallo, and Tomuka (2016), the slower the vehicle on the road, the higher the severity of the patient's condition due to traffic accidents. On the other hand, this 68-yearold patient was also diagnosed with brain hemorrhage and open fracture femur, systolic blood pressure $(78 \mathrm{mmHg})$, heart rate $(39 \mathrm{x} / \mathrm{min})$, respiratory rate (5x/min), SPO2 (74) \%), and GCS (3). Hemorrhagic brain can increase intracranial pressure, which increases the risk of cerebral hypoxia (lack of oxygen), cerebral necrosis, cerebral ischemia, brain tissue edema, and brain herniation. Open fracture femurs can cause massive bleeding according to the location of the fracture and its trauma ( Sheehy, 2013; Ulya et al., 2017). These conditions can increase patient's risk of mortality.

In addition to the types of trauma above, the patients' vital signs are in the abnormal range. According to $\mathrm{Ha}$ et al. (2017), the vital signs of patients experiencing the risk of mortality are patients with abnormal vital signs and as much as $5 \%$ risk of mortality with respiratory distress from the first eight hours to 48 hours. Systolic blood pressure, GCS, and RR also affect the risk of mortality. The lower the value of systolic blood pressure, GCS, and RR the higher risk of mortality (Ristanto et al., 2016). SBP ( $<90 \mathrm{mmHg}$ ) can predict the risk of patient mortality (Liu et al., 2012). If the SpO2 is lower (<90\%), it can increase the risk of mortality within 24 hours (Ha et al., 2017).Age also plays a role in determining the level of risk of mortality in trauma patients. Lingsma, Roozenbeek, Steyerberg, Murray, and Maas (2010), showed that the older the age of the patients, the worse their condition. This was caused by decreased neurological function and disability conditions increased.

The role in vehicle use has significant relationship with risk of mortality $(p=0.043)$. The role in vehicle use as drivers often experiences traffic accidents (68.4\%). Drivers had the risk of mortality (67.8\%) due to traffic accident in Tomohon. This incident was caused by an undisciplined driver using a seat belt, on the motorist's helmet and completeness of the letter, the condition of the driver who was tired, drunk (or the influence of alcohol and drugs) and / or sleepy (Rompis et al., 2016). Drivers had 66,2\% experience of traffic accidents (Angela et al., 2013). Thus, researchers assume that drivers have higher risk of mortality due to traffic accidents.

The age group of 20-29 years often experiences traffic accidents (19.6\%). Generally traffic accidents at Guilan Province Medical Center occur in the age group of 20-29 years (32.2\%) (Amiri et al., 2016). Other studies show that ages 21-30 years dominate traffic accidents (33.46\%) (Yogesh, 2015). So it can be seen that the productive age group and adult contribute in the occurrence of traffic accidents. This is because these age groups have anger and are less stable. As a result, there is lack level of caution and discipline in using vehicles and roads (Rompis et al., 2016). Researchers assume that traffic accidents often occur in the age group 21-29 years with status as students and workers due to the time when the accident happened; 6 am to $11.59 \mathrm{am}$ is the time where students go home and go to school. However, based on Chi-square test, there is no significant relationship between the age group and risk of mortality ( $\mathrm{P}=0.427)$.

Type of road user who frequently experience traffic accidents are 2-wheeled or 3-wheeled motor riders (73.2\%). Motorcycle users often experience traffic accidents (53.78\%) (Wicaksono et al, 2014). Another study explained that the number of motorcycle users who experienced traffic accidents was 65\% (Herawati, 2014). This is due to an increase in the number of motorized vehicles, which in developing countries sees an increase occurred in two-wheeled motor vehicles and buses (Nugroho \& Yulianti, 2016). On the other hand, drivers and passengers of motorized vehicles are not protected by security as are car drivers (Rompis et al., 2016). Researchers assume that two or three-wheeled motorized vehicle users have a vulnerability to traffic accidents due to lack of safety driving behavior. However, the Chi-square test showed no significant relationship between type of vehicle and the risk of mortality ( $p=0.122>0.05)$.

Traffic accident patients at the ED of dr. Soebandi Regional Hospital, Jember Regency, in 2018 often occurred from 06.00-11.59am (morning) (37.6\%). This research is in line with the results of Herawati's research (2014), stating that the highest number of traffic accidents occurred 06.00-12.00am and 12.0018.00 pmeach as much as $31 \%$. Most traffic accidents occurred at $12.00-18.00 \mathrm{pm}$ (31.74\%) (Wicaksono et al., 2014). Other research also explains that 12.0018.00 pmis a time that often occurs traffic accidents, by $44 \%$ (Saputra, 2017). This is because at $06.00-$ 
11.59am and 12.00-17.59pmare the peak of outdoor activities, which means that people tend to go out at the same time, either for going to school or having lunch, so that the level of traffic accidents is greater (Rompis et al., 2016). Although traffic accident tends to increase in a specific time, there is no significant relationship between time of traffic accident and risk of mortality (Chi-square test $\mathrm{p}=0.070>005$ ).

Furthermore, the number of male patients in the ED of dr. Soebandi Regional Hospital due to traffic accidents reached $68.4 \%$. But the gender does not have significant relationship with risk of mortality ( $p$ $=0.299>0.05$ ). Male dominates the incident of traffic accidents by $88.5 \%$ (Katageri et al., 2015). The fatalities were primarily male (98.5\%) (Kotwal et al., 2019). The ratio of injuries due to traffic accidents between men and women is 8.4: 1 (Hosseinpour et al., 2017). Furthermore, traffic accident victims who experienced mortality in the city of Tomohon for the 2012-2014 period were 84.75\% men (84.75\%) (Rompis et al., 2016). Gender which frequently experiences traffic accidents is men. Factors that cause an increase in traffic accidents in men are behavior patterns in driving, mobility levels, and male dominance on the road (Oktavianti, 2016; Rompis et al., 2016).

In this study, traffic accident patients experienced head trauma (57.2\%), and lower limb trauma (40.0\%). Lower extremities consist of femur, tibia, fibula, patella, tarsal, metatarsal, and phalanges (Ros \& Wilson, 2014). Other studies also explained that head trauma due to traffic accidents reached $87.8 \%$ and external trauma as much as $92.8 \%$ (Nugroho\& Yulianti, 2016). The type of trauma that usually occurs in traffic accident victims is extremity trauma as much as $28 \%$ (Yogesh et al ., 2015). Generally, head and neck trauma is experienced by victims of traffic accidents by $26.4 \%$ (Amiri et al., 2016). Head trauma is caused due to negligence in the use of helmets. The use of helmets can reduce the incidence of severe head injuries by $70 \%$. Traumatic injuries also often occur due to traffic accidents because of primary impact or secondary impact; secondary impact is caused by a collision with an opposing vehicle and / or highway (Oktavianti, 2016). The highest mortality rates occur in patients with chest trauma (22.2\%) and head trauma (14.7\%) (Fouda et al., 2016). This research result showed no significant relationship between type of trauma and risk of mortality ( $p=$ 0.689).

The limitation of this study was it only analyzed medical record patients in one year and only in one hospital. This study cannot show risk of mortality trend due to regulation change that makes patients go to first referral hospitals.

\section{CONCLUSION}

The conclusion of this research was that almost all patients with traffic accident in the ED dr.Soebandi regional hospital (94.8\%) had low risk of mortality. Traffic accidents often occured in the age group of 20 to 29 years $(19.6 \%)$ and the male group (68.4\%). Traffic accidents were often experienced by riders of 2 or 3-wheeled motor vehicles (73.2\%), while the highest type of trauma in traffic accident patients was head trauma $(41.7 \%)$. There was a significant relationship between the role in vehicle use with the risk of mortality. Future studies can focus on the prevention risk of mortality for patients due to traffic accidents according to role in vehicle use. The clinical implication of this research is a source of data for health workers to make clinical decisions at various levels risk of mortality for patients with traffic accidents. This is expected to prevent worsening in the patient's condition.

\section{REFERENCES}

Amiri, Z. M., Dastgiri, S., Davoudi-kiakalyeh, A., Imani, A., \& Mollarahim, K. (2016). An Epidemiological Study of Road Traffic Accidents in Guilan Province, Northern Iran in 2012. Bull Emerg Trauma, 4(4), 230-235.

Deviantony, F., Ahsan, \& Setyoadi. (2017). Analisis Faktor yang Berhubungan dengan Waktu Tunggu Pasien Setelah Keputusan Rawat Inap Diputuskan di Zona Kuning Instalasi Gawat Darurat RSD dr.Iskak Tulungagung. 2(2).

Eaton, J., Grudziak, J., Bilal, A., Chisenga, W. C., Hadar, E., \& Charles, A. (2017). The effect of anatomic location of injury on mortality risk in a resourcepoor setting. Journal Injury, 48(7), 1432-1438. https://doi.org/10.1016/j.injury.2017.05.023

Fouda, E. Y., Youssef, M., \& Emile, S. H. (2016). Pattern of Major Injuries After Motorcycle Accidents in Egypt: The Mansoura Pattern of Major Injuries After Motorcycle Accidents in Egypt: The Mansoura Emergency Hospital experience. Journal Sage, 19(June), 39-45. https://doi.org/10.1177/1460408616652924

Ha, D. T., Dang, T. Q., Tran, N. V, Pham, T. N. T., Nguyen, N. D., \& Nguyen, T. V. (2017). Development and Validation of a Prognostic Model for Predicting 30Day Mortality Risk in Medical Patients in Emergency Department (ED). Nature Publishing Group, https://doi.org/10.1038/srep46474

Herawati. (2014). Karakteristik dan Penyebab Kecelakaan Lalu Lintas di Indonesia Tahun 2012. Warta Penelitian Perhubungan, 26, 133-142.

Hosseinpour, M., Mohammadian-Hafshejani, AbdollahEsmaeilpour Aghdam, M. M., \& Mahdi Maleki, F. (2017). Trend and Seasonal Patterns of Injuries and Mortality Due to Motorcyclists Traffic Accidents; A Hospital-Based Study. Journal Emerg Trauma, 5(1), 47-52.

ILO. (2018). Tujuan Pembangunan Millenium; Referensi Manual Serikat Pekerja pada Agenda untuk Pembangunan Berkelanjutan 2030. Jakarta: Organisasi Perburuhan Internasional.

Katageri, S., Sharma, R. B., Govindaraju, H. C., \& Singh, A. K. (2015). Pattern of Injuries in Road Traffic Accidents at Chitradurga Karnataka: An Autopsy 
Based Study. Journal of Indian Academy of Forensic Medicine, 37(2), 173-175. https://doi.org/10.5958/09740848.2015.00042.1

Korlantas Polri. (2019). Korlantas Polri.

Lingsma, H. F., Roozenbeek, B., Steyerberg, E. W., Murray, G. D., \& Maas, A. I. (2010). Early prognosis in traumatic brain injury: from prophecies to predictions. The Lancet Neurology, 9(5), 543-554. https://doi.org/10.1016/S1474-4422(10)70065$\mathrm{X}$

Liu, Y., Liu, J., Fang, Z. A., Shan, G., Xu, J., Qi, Z., ... Yu, X. (2012). Modified Shock Index and Mortality Rate of Emergency Patients. World J Emerg Med, 3(2), 114-117.

Miller, R. T., Nazir, N., Mcdonald, T., \& Cannon, C. M. (2017). The Modified Rapid Emergency Medicine Score : A Novel Trauma Triage Tool to Predict inHospital Mortality. Injury, 8. https://doi.org/10.1016/j.injury.2017.04.048

Nugroho, A. A., \& Yulianti, K. (2016). Karakteristik luka pada korban kecelakaan lalu lintas di instalasi kedokteran forensik rsup sanglah pada tahun 2012. E-Jurnal Medika, 5(3).

Nursalam. (2015). Metodologi Penelitian Ilmu Keperawatan: Pendekatan Praktis. Jakarta: Salemba Medika.

Oktavianti, P. H. (2016). Prevalensi dan Gambaran Pola Luka Korban Kecelakaan Sepeda Motor di Instalasi Forensik RSUP Sanglah Denpasar Tahun 2013 Putu Herlin Oktavianti Program Studi Pendidikan Dokter , Fakultas Kedokteran Universitas Udayana ABSTRAK Kecelakaan lalu lintas merupak. Directory Of Open Access Journals, 7(1), 33-41. https://doi.org/E-ISSN: 2503-3638

Ristanto, R., Indra, M. R., Poeranto, S., \& Setyorini, I. (2016). Kata kunci: Mortality, Pasien Cedera
Kepala, RTS. Jurnal Kesehatan Hesti Wira Sakti, 4, 76-90.

Rompis, A., Mallo, J., \& Tomuka, D. (2016). Kematian Akibat Kecelakaan Lalu Lintas Kota Tomohon tahun 2012-2014. Jurnal E-CliniC, 4(1). https://doi.org/10.35790/ecl.4.1.2016.10837

Saputra, A. D. (2017). Studi Tingkat Kecelakaan Lalu Lintas Jalan di Indonesia Berdasarkan Data KNKT ( Komite Nasional Keselamatan Transportasi ) Dari Tahun 2007-2016. Warta Penelitian Perhubungan, 29(2), 179-190.

Sastroasmoro, S., \& Ismael, S. (2014). Dasar-Dasar Metodologi Penelitian Klinis (5th ed.). Jakarta: Cv. Sagung Seto.

Seak, C., Yen, D. H., Ng, C., \& Wong, Y. (2017). Rapid Emergency Medicine Score : A novel prognostic tool for predicting the outcomes of adult patients with hepatic portal venous gas in the emergency department. $1-9$.

Sugiyono. (2015). Statistik untuk Penelitian. Bandung: Alfabeta.

Wahyunik, S. (2019). Laka Lantas di Jalan Basuki Rahmat Jadi Kasus Kecelakaan Pertama yang Terjadi di Jember pada 2019 - Tribun Madura. Jember.

WHO. (2018). Global Status Report On Road Safety 2018.

Wicaksono, D., Fathurochman, R. A., \& Riyanto, B. (2014). Analisis Kecelakaan Lalu Lintas. Jurnal Karya Teknik Sipil, 3, 203-213.

Yogesh, G. (2015). Pattern Of Injuries In Fatal Road Traffic Accidents : Autopsy Based Study. Journal of Evidence Based Med \& Hlthcare, 2(4), 321-327. 